\title{
Perlindungan Hak Asasi Manusia oleh Pemerintah pada Masa Pandemi COVID-19
}

\author{
Anang Dony Irawan*, Kaharudin Putra Samudra, Aldiansah Pratama \\ Universitas Muhammadiyah Surabaya, Indonesia
}

\begin{abstract}
Abstrak-Perlindungan Hak Azazi Manusia (HAM) adalah tindakan atau upaya untuk melindungi masyarakat dari perbuatan sewenang-wenang oleh penguasa yang tidak sesuai dengan aturan hukum, untuk mewujudkan ketertiban dan ketentraman sehingga memungkinkan manusia untuk menikmati martabatnya sebagai manusia. Hubungan hukum selalu menimbulkan hak dan kewajiban yang timbal balik, hak dari pihak yang satu menjadi kewajiban pihak yang lain dan sebaliknya. Sebagai subyek hukum yang telah menjalankan tugas pelayanannya dalam koridor hukum yang benar, pada hakikatnya masyarakat berhak mendapatkan perlindungan hukum dari kaidah-kaidah hukum positif yang berlaku. Pasal 28D ayat (1) UUD 1945 menyebutkan bahwa setiap orang berhak atas pengakuan, jaminan, perlindungan, dan kepastian hukum yang adil serta perlakuan yang sama dihadapan hukum. Pasal 27 ayat (1) UU No. 36/2009 tentang Kesehatan menyebutkan bahwa tenaga kesehatan berhak mendapatkan imbalan dan pelindungan hukum dalam melaksanakan tugas sesuai dengan profesinya. Ketidakjelasan prediksi dari para ahli mengenai berakhirnya pandemi Covid-19 menyebabkan pasar ekonomi mengalami banyak spekulasi dan ketidakstabilan. Covid19 menyebabkan terhentinya transaksi jual beli yang secara konvensional merupakan salah satu hal yang paling esensial dari aktivitas ekonomi sebagai akibat adanya kebijakan PSBB maupun karantina. Selama pandemi Covid-19 masih menyebar maka dapat dipastikan mayoritas transaksi ekonomi akan terhenti atau setidaktidaknya mengalami gangguan.
\end{abstract}

\author{
Kata kunci: \\ Hak Atas Kesehatan, \\ Pandemi COVID-19, \\ Perlindungan HAM
}

Histori:

Dikirim: 23 Februari 2021

Direvisi: 10 Maret 2021

Diterima: 14 Maret 2021

Online: 18 Maret 2021

\section{Identitas Artikel:}

Irawan, A. D., Samudra, K. P., \& Pratama, A. (2021). Perlindungan Hak Asasi Manusia oleh Pemerintah pada Masa Pandemi COVID-19. Jurnal Citizenship Virtues, 1(1), 1-6.

\section{PENDAHULUAN}

Awal tahun 2020 China telah memberikan alarm kepada dunia akan bahaya SARSCov-2 atau Corona Virus Disease 2019 (COVID-19). Sejak peringatan itu, beberapa negara telah mewaspadai akan mewabahnya virus ini. Pengkajian singkat oleh Pusat Pemodelan Matematika dan Simulasi Institut Teknologi Bandung memperkirakan pandemi ini akan mencapai puncaknya pada akhir Maret dan

\footnotetext{
*Corresponding author

E-mail: anangdonyirawan@fh.um-surabaya.ac.id
} 
berakhir pada pertengahan April 2020. Bahkan dengan kedinamisan data yang ada, prediksi tersebut tentu dapat terus berubah (CNN Indonesia, 2020).

Tepat pada tanggal 10 April 2020 merupakan hari ke 40 setelah Presiden mengumumkan adanya pasien yang terjangkit COVID-19 untuk pertamakalinya di Indonesia. Kasus Positif COVID-19 terus mengalami peningkatan seperti yang telah terkonfirmasi bahwa jumlah kasus positif hingga Senin (13/4/2020) mencapai 4.557 kasus. Dari jumlah tersebut menunjukkan adanya lonjakan terus menerus di setiap harinya. Kini jumlah pasien meninggal dunia mencapai 399 orang (KOMPAS, 2020). Lambannya Pemerintah dalam mengantisipasi virus menimbulkan permasalahan di setiap aspek, baik sosial, ekonomi dan politik. Pada tanggal 10 Maret 2020 Direktur Jenderal World Health Organization telah mengirim surat kepada Presiden RI untuk mempertanyakan tingkat kesiapan Indonesia dalam menghadapi pandemi global. Keterbukaan pemerintah dalam menangani kasus hingga menyoroti pendekatan dalam melacak dan mendeteksi kasus COVID-19 (Purnomo, 2020).

Perlindungan HAM adalah tindakan atau upaya untuk melindungi masyarakat dari perbuatan sewenang-wenang oleh penguasa yang tidak sesuai dengan aturan hukum, untuk mewujudkan ketertiban dan ketentraman sehingga memungkinkan manusia untuk menikmati martabatnya sebagai manusia. Demikian pula halnya dengan masyarakat yang bergabung dalam gugus tugas percepatan penangan COVID-19. masyarakat yang bergabung yang merupakan salah satu unsur dari sumber daya kesehatan juga mempunyai kewajiban untuk menjalankan tugas pelayanannya secara profesional. Mengingat masyarakat yang bergabung ini adalah subyek hukum, maka pada intinya hubungan yang terjadi antara masyarakat, pasien dan sarana kesehatan merupakan hubungan hukum. Hubungan hukum selalu menimbulkan hak dan kewajiban yang timbal balik, hak dari pihak yang satu menjadi kewajiban pihak yang lain dan sebaliknya. Sebagai subyek hukum yang telah menjalankan tugas pelayanannya dalam koridor hukum yang benar, pada hakikatnya masyarakat berhak mendapatkan perlindungan hukum dari kaidahkaidah hukum positif yang berlaku.

Raharjo (2000) dalam bukunya yang berjudul Ilmu Hukum mengemukakan bahwa perlindungan hukum adalah memberikan pengayoman terhadap Hak Asasi Manusia (HAM) yang dirugikan orang lain dan perlindungan itu diberikan kepada masyarakat agar dapat menikmati semua hak-hak yang diberikan oleh hukum. Soekanto (1984) dalam bukunya yang berjudul Pengantar Penelitian Hukum, mengemukakan bahwa perlindungan hukum adalah segala upaya pemenuhan hak dan pemberian bantuan untuk memberikan rasa aman kepada saksi dan atau korban, yang dapat diwujudkan dalam bentuk seperti melalui restitusi, kompensasi, pelayanan medis, dan bantuan hukum.

\section{METODE PENELITIAN}

Dalam penulisan makalah ini, metode yang digunakan adalah pendekatan yuridis normatif, yaitu penulisan yang menekankan pada penafsiran hukum positif dan menganalisa dengan menggunakan bahan-bahan kepustakaan, norma-norma hukum tertulis. Bila dilihat dari sifat penulisan, maka metode yang digunakan adalah menggunakan metode yang bersifat deskriptif analistis, yaitu mencoba menggambarkan gejala yang timbul dalam masyarakat dan masalah yang timbul 
didalamnya serta mencoba menganalisa dan memberikan suatu solusinya. Dalam metode yang digunakan ini mendasarkan pada data serta informasi yang bersifat umum, diantaranya Peraturan Perundang-undangan, teori maupun doktrin, dan pendapat ahli.

\section{HASIL DAN PEMBAHASAN}

Perlindungan HAM dalam Gugus Tugas Percepatan Penanganan COVID-19

Pasal 28D ayat (1) UUD 1945 menyebutkan bahwa setiap orang berhak atas pengakuan, jaminan, perlindungan, dan kepastian hukum yang adil serta perlakuan yang sama dihadapan hukum. Hal ini serupa dengan Pasal 5 ayat (1) UndangUndang Nomor 39 Tahun 1999 tentang Hak Asasi Manusia yang juga menyebutkan bahwa setiap orang diakui sebagai manusia pribadi yang berhak menuntut dan memperoleh perlakuan serta perlindungan yang sama sesuai dengan martabat kemanusiaannya di depan hukum.

Pasal 27 ayat (1) Undang-Undang Nomor 36 Tahun 2009 tentang Kesehatan menyebutkan bahwa tenaga kesehatan berhak mendapatkan imbalan dan pelindungan hukum dalam melaksanakan tugas sesuai dengan profesinya. Diperkuat dengan Pasal 57 huruf a Undang-Undang Nomor 36 Tahun 2014 tentang Tenaga Kesehatan yang juga menyebutkan bahwa tenaga kesehatan dalam menjalankan praktik berhak memperoleh pelindungan hukum sepanjang melaksanakan tugas sesuai dengan Standar Profesi, Standar Pelayanan Profesi, dan Standar Prosedur Operasional. Peraturan tersebut, memberikan kewenangan kepada Pemerintah untuk menjalankan perintah hukum dalam memberikan jaminan atas perlindungan hukum kepada tenaga kesehatan. Sehubungan dengan gugus tugas penanganan percepatan COVID-19, maka Pemerintah memiliki kewajiban memberikan pengayoman dan mejamin hak-hak tenaga kesehatan dalam melakukan pelayanan termasuk di dalamnya adalah imbalan dan jaminan atas keselamatan dan kesehatan selama bertugas.

Raharjo (2000) menyatakan bahwa, perlindungan hukum adalah memberi pengayoman terhadap Hak Asasi Manusia (HAM) yang dirugikan orang lain dan perlindungan itu diberikan kepada masyarakat agar dapat menikmati semua hakhak yang diberikan oleh hukum. Secara konstitusional Pemerintah wajib memberikan pelayanan kesehatan yang memadai, dan masyarakat berhak untuk mendapatkan perlindungan sebagai hak yang melekat, maka perlindungan serta jaminan kesehatan setiap orang merupakan garda terdepan. Kewajiban Pemerintah dalam memenuhi hak konstitusional masyarakat atas kesehatan memiliki landasan yuridis internasional yakni dalam Pasal 2 ayat (1) Konvensi Hak Ekonomi, Sosial dan Budaya. Kemudian konstitusi secara nasional pun telah menyebutkan dalam pasal 28I ayat (4) UUD 1945 menyatakan bahwa perlindungan, pemajuan, penegakan, dan pemenuhan hak asasi manusia adalah tanggung jawab negara, terutama pemerintah. Kewajiban pemerintah ini juga ditegaskan dalam Pasal 8 UU HAM, kemudian Pasal 7 UU Kesehatan yang menyatakan bahwa pemerintah bertugas menyelenggarakan upaya kesehatan yang merata dan terjangkau oleh setiap masyarakat. Kemudian Pasal 9 UU Kesehatan menyatakan bahwa pemerintah bertanggung jawab untuk meningkatkan derajat kesehatan masyarakat.

Upaya pemenuhan hak atas kesehatan dapat dilakukan dengan berbagai macam cara yang berupa pencegahan dan penyembuhan. Upaya pencegahan meliputi 
penciptaan kondisi yang layak bagi kesehatan, baik menjamin ketersediaan pangan dan pekerjaan, perumahan yang baik, dan lingkungan yang sehat. Sedangkan upaya penyembuhan dilakukan dengan penyediaan pelayanan kesehatan yang optimal.

Pelayanan kesehatan meliputi aspek jaminan sosial atas kesehatan, sarana kesehatan yang memadai, tenaga medis yang berkualitas, dan pembiayaan pelayanan yang terjangkau oleh masyarakat. Pasal 12 Konvensi Hak Ekonomi, Sosial, dan Budaya diuraikan pula langkah-langkah yang harus diambil untuk mewujudkan standar tertinggi dalam mencapai kesehatan fisik dan mental (ELSAM: 3), yaitu: (1) peningkatan semua aspek kesehatan lingkungan dan industri; (2) pencegahan, perawatan dan pengendalian segala penyakit menular endemik, penyakit yang berhubungan dengan pekerjaan dan penyakit lainnya; (3) penciptaan kondisi-kondisi yang menjamin adanya semua pelayanan dan perhatian medis ketika penyakit timbul.

\section{Harmonisasi Kebijakan Pemerintah Sebagai Upaya Pemenuhan Hak Asasi Manusia Dalam Penanganan COVID-19}

Dengan berpegang pada prinsip "salus populi suprema lex esto" keselamatan rakyat merupakan hukum tertinggi (Powell, 2006). maka kebijakan kesehatan dalam rangka penyelamatan, pencegahan, maupun penyembuhan dari COVID-19 harus menjadi prioritas pertama (Arde-Acquah, 2014). Karenanya, upaya penerapan PSBB yang dilakukan oleh Pemerintah Indonesia, yang secara praktis berkombinasi dengan karantina mandiri yang dilakukan oleh warga tempat PSBB diterapkan, membuat persoalan perekonomian muncul, karena terhalangnya aktivitas ekonomi warga akibat pembatasan, sehingga Pemerintah baik pusat maupun daerah harus bertanggung jawab memberikan bantuan sosial kepada warga miskin dan warga terdampak dari kebijakan PSBB tersebut. Dengan demikian, walau aktivitas warga dibatasi dalam rangka pemenuhan hak kesehatan akibat adanya COVID-19, namun hak ekonomi warga khususnya hak untuk terbebas dari kelaparan harus tetap dipenuhi. Dalam praktik, sering kali muncul masalah khususnya dari sisi pendataan, namun secara konsptual, kebijakan PSBB yang diiringi dengan bantuan sosial menunjukkan telah ada harmonisasi antara pemenuhan hak kesehatan dan hak ekonomi.

Namun demikian, permasalahan baru timbul yang disebabkan oleh ketidakpastian kapan akan berakhirnya pandemi COVID-19. Banyak prediksi yang diajukan, namun belum mampu menjawab secara pasti berakhirnya COVID-19. Misalnya prediksi para ilmuwan dari Singapore University of Technology and Design (SUTD), pandemi COVID-19 akan berakhir pada 1 September 2020 (Franedya, 2020). Sedangkan menurut para ilmuan yang berasal dari Institut Teknologi Sepuluh November (ITS) Surabaya dan Universitas Gadjah Mada (UGM) Yogyakarta memprediksi bahwa pandemi COVID-19 akan selesai pada akhir Mei 2020 (Sawitri, 2020). Bahkan sampai dengan makalah ini ditulis pada awal Desember 2020. Prediksi berakhirnya COVID-19 di akhir September 2020 tersebut tidak terbukti.

Ketidakjelasan prediksi dari para ahli mengenai kapan berakhirnya pandemi COVID-19 menyebabkan pasar ekonomi mengalami banyak spekulasi dan ketidakstabilan. Bahkan, dikarenakan vaksin guna mengobati dan mencegah COVID-19 belum tersedia, mengakibatkan virus ini seperti bola salju yang terus menggelinding dan membesar yang berpotensi menghancurkan ekonomi. Tidak 
lain, karena pandemi COVID-19 menyebabkan terhentinya transaksi jual beli yang secara konvensional merupakan salah satu hal yang paling esensial dari aktivitas ekonomi sebagai akibat adanya kebijakan PSBB maupun karantina. Selama pandemi COVID-19 masih menyebar maka dapat dipastikan mayoritas transaksi ekonomi akan terhenti atau setidak-tidaknya mengalami gangguan.

Sementara itu, daya tahan ekonomi warga terbatas, sehingga sangat mungkin menimbulkan persoalan ekonomi tidak hanya bagi warga miskin, melainkan juga yang sebelumnya tidak miskin. Daya tahan perusahaan atau usaha yang terkena dampak pembatasan kegiatan karena adanya kebijakan PSBB-pun cukup terbatas, sehingga memungkinkan adanya gelombang pemutusan hubungan kerja (PHK) yang secara langsung akan berdampak pada terganggunya hak ekonomi warga negara. Demikian halnya dengan kemampuan negara dalam memberikan subsidi bagi warganya. Hal yang selama ini kurang diungkap oleh Pemerintah mengenai kemampuan negara dalam menopang warga yang terdampak COVID-19, baik dari segi anggaran maupun waktu. Karena itu, dari segi hak ekonomi, tidak hanya hak untuk terbebas dari kelaparan yang terancam, melainkan juga hak atas pekerjaan dan penghidupan yang layak, hak mendapat imbalan dari pekerjaan, hak mendapat perlakuan yang adil dan layak dalam hubungan kerja, dan hak bebas untuk memilih pekerjaan yang dijamin Pasal 27 Ayat (2), Pasal 28D Ayat (2) dan Pasal 28E Ayat (1) UUD 1945.

\section{KESIMPULAN}

Penetapan keputusan Presiden terbilang sangat lamban. Hal ini menimbulkan dampak yang serius dalam menjaga keseimbangan negara antara melindungi kesehatan, meminimalkan gangguan ekonomi dan sosial, serta menghormati hak asasi manusia di tengah pandemi ini. Karena dengan adanya pandemi ini tidak hanya berdampak pada kesehatan masyarakat, krisis ini akan berdampak pada setiap sektor. Pandemi COVID-19 telah menyebabkan krisis dan kedaruratan yang termasuk ke dalam welfare emergency. Sifat kedaruratan COVID-19 tidak hanya bagi kesehatan, melainkan juga terhadap perekonomian secara bersamaan sebagai akibat belum ditemukan secara pasti, kapan pandemi COVID-19 berakhir. Dalam perspektif hak asasi manusia, hak asasi manusia dalam penanganan pandemi COVID-19 adalah tidak tepat bahkan bentuk kesesatan/misleading. Karena, baik ekonomi maupun kesehatan sama-sama hak asasi manusia yang tidak dapat dibagi (indivisibility), saling bergantung (interdependent), saling terkait (interrelated), dan tidak dicabut (inalienable). Darurat kesehatan akibat COVID-19 juga telah mengakibatkan darurat ekonomi. Untuk itu, penanganan COVID-19 dari sisi ekonomi dan kesehatan harus dijalankan secara harmonis dan beriringan berbasiskan hak asasi manusia. Prinsip keselamatan rakyat sebagai hukum tertinggi harus dipegang secara kuat, sehingga kebijakan penanganan COVID-19 baik secara kesehatan dan ekonomi mengarusutamakan kesehatan

\section{REFERENSI}

Arde-Acquah, P. E. (2014). Salus Populi Supreme Lex Estp: Balancing Civil Liberties and Public Health Interventions in Modern Vaccination Policy. Wash. U. Jurisprudence Rev., 7, 337. 
CNN Indonesia. (2020). ITB: Puncak Corona RI Akhir Maret, Berakhir Tengah April 2020 [HTML file]. Tersedia: https://www.cnnindonesia.com/teknologi/20200319142837-199-484974/itbpuncak-corona-ri-akhir-maret-berakhir-tengah-april-2020

Franedya, R. (2020). Ilmuwan Singapura Prediksi Corona Hilang dari RI di September [HTML file]. Tersedia: https://www.cnbcindonesia.com/tech/20200430123251-37-155499/ilmuwansingapura-prediksi-corona-hilang-dari-ri-di-september.

KOMPAS. (2020). 4.557 Orang Positif Corona di Indonesia, Lonjakan Kasus Tertinggi di DKI Jakarta [HTML file]. Tersedia: https://www.kompas.com/tren/read/2020/04/13/174836965/4557-orangpositif-corona-di-indonesia-lonjakan-kasus-tertinggi-di-dki

Powell, J. G. (2006). M. Tulli Ciceronis De re publica, De legibus, Cato maior de senectute, Laelius de amicitia. Oxford: Oxford University Press.

Purnomo, W. A. (2020). Menyangkal Krisis Menuai Bencana [HTML file]. Tersedia: https://majalah.tempo.co/read/laporan-utama/159957/salah-langkahjokowi-hadapi-wabah-corona.

Raharjo, S. (2000). Ilmu Hukum. Bandung: PT. Citra Aditya Bakti.

Sawitri, Y. M. (2020). Prediksi Pakar Soal Akhir Wabah Virus Corona Covid-19 di Indonesia [HTML file]. Tersedia: https://www.liputan6.com/bola/read/4220216/prediksi-pakar-soal-akhirwabah-virus-corona-covid-19-di-indonesia.

Soekanto, S. (1984). Pengantar Penelitian Hukum. Jakarta: UI Press. 